\section{Postharvest Losses of Mechanically Injured Onions after Curing}

\author{
Kil Sun Yoo ${ }^{1}$ and Leonard M. Pike ${ }^{2}$ \\ Vegetable Improvement Center, Department of Horticultural Sciences, Texas \\ A\&M University, College Station, TX 77843
}

Additional index words. Allium cepa, Aspergillus niger, Botrytis spp., handling

Texas spring onions are harvested between late March and May when temperatures are usually $>30$ C. Spring onions are generally softer and more succulent than the fall onions harvested in northern states; thus, spring onions are more susceptible to mechanical damage and subsequent secondary infection that often occurs during transit or temporary storage under warm, humid, or improperly ventilated conditions.

Field or forced-air curing is the general practice that reduces losses during storage (Hardenburg et al., 1986). However, onions are subjected to additional damage during grading, packaging, and transporting. Previous curing research describes curing before main storage, but to our knowledge, there is no published research to determine the losses due to packaging damage.

This study determined postharvest onion losses, caused by artificial wounding that simulated packaging damage, and demonstrated that onions can be cured without incurring secondary infection if properly ventilated.

'Texas Grano 1015Y' onion bulbs were hand-harvested on $30 \mathrm{Apr}$. from the Rio Grande Valley, Texas, and were graded for diameter uniformity $(7.5 \pm 1 \mathrm{~cm})$. They then were cured 1 week at $24 \pm 2 \mathrm{C}$ and $40 \%$ to $50 \%$ relative humidity $(\mathrm{RH})$ with forced ventilation by a fan. We used three mechanical injury treatments: 1) onion bulbs were cut vertically with a serrated knife $\approx 5 \mathrm{~mm}$ deep at four locations equally spread around the bulb equators (cut), 2) bulbs were dropped twice onto a flat hard surface from a height of $80 \mathrm{~cm}$ (drop), 3) bulbs were cut then dropped (cut + drop). The controls were not injured.

Each treatment consisted of four boxes (total 160 to 180 bulbs per treatment) as repli-

Received for publication 10 Aug. 1994. Accepted for publication 9 Nov. 1994. The cost of publishing this paper was defrayed in part by the payment of page charges. Under postal regulations, this paper therefore must be hereby marked advertisement solely to indicate this fact.

${ }^{1}$ Research Assistant Professor.

${ }^{2}$ Professor. cations. Each 22.7-kg corrugated box contained 40 to 45 treated bulbs. The box measured $40 \times 60 \times 27 \mathrm{~cm}$ and was provided with 20 holes $(6.5 \mathrm{~cm}$ in diameter) around the box (Pike et al., 1989). Four boxes of onions were placed in each layer and were stacked four high on a wood pallet $(120 \times 120 \mathrm{~cm})$ with the holes aligned. The boxes were restacked randomly every week after each measurement. Storage was in a room at $24 \pm 2 \mathrm{C}$ with $40 \%$ to $50 \% \mathrm{RH}$ for 5 weeks. The air in the room was circulated by a fan and no forced-air movement through the boxes was provided.

Water loss rate, which includes some weight loss due to respiration, was calculated from the weight decrease in boxes between the initial and weekly evaluation and were expressed as grams $\mathrm{H}_{2} \mathrm{O}$ per kilogram onion per day. Percent decay was calculated from number of decayed bulbs caused by Botrytis spp. Percent black mold was calculated from number of bulbs infected by Aspergillus niger Tiegh. on the cut surfaces. These Botrytis-decayed bulbs were discarded, but molded bulbs were returned to the box. Cumulative weekly total weight loss was calculated from weight losses due to water loss (drying) and Botrytis decay and were expressed as a percentage. All data were subjected to analysis of variance with mean separation by Duncan's multiple range test. Percent data were arcsin-transformed before analysis. $2 \mathrm{C}$ and $40 \%$ to $50 \%$ relative humidity for 5 weeks. by Botrytis decay.
Onions in the cut and cut + drop treatments lost more than twice as much water per day as those in the drop only or control treatments (Table 1). However, the water loss rates were similar for the drop and control treatments. As the curing proceeded, water loss from the cut or cut + dropped onions tended to decrease. During the first week, total weight loss was $\approx 3$ times as great in the cut and cut + drop treatments as in the other two treatments (Table 1). The difference among cut, cut + drop, and control treatments decreased as the storage period progressed. Total weight loss was mainly due to water loss during the first 3 weeks and then by decay. The percentage of Botrytis decay was random and statistically insignificant but contributed to weight loss (data not presented). Total weight loss for the control and the drop only treatment were about half of that for the cut or cut + drop treatments during 3 weeks. After 5 weeks, all injured lots had lost at least twice as much weight as the controls. Under the low RH and good air exchange conditions of this test, the cut surfaces cured so well that incidence of black mold on the cuts was minor $(<0.1 \%)$. The impacted surface also cured without measurable losses.

Our studies show that decay or fungal growth on the surface of damaged onions may be avoided by proper ventilation, using $40 \%$ to $50 \% \mathrm{RH}$ at $24 \mathrm{C}$ to quickly dry the damaged bulbs. Drying proved to be an effective deterrent to microbial infection, hastened the closing of wounds, and reduced further water loss.

\section{Literature Cited}

Hardenburg, R.E., A.E. Watada, and C.Y. Wang. 1986. The commercial storage of fruits, vegetables, and florist and nursery stocks. U.S. Dept. Agr., Agr. Hdbk. 66.

Pike, L.M., K.S. Yoo, and T.H. Camp. 1989. A comparison between bags and boxes for shipping Texas short-day onions. HortScience 24:631-632

Table 1 . Water loss rate and percent total weight loss of mechanically damaged onion bulbs stored at $24 \pm$

\begin{tabular}{|c|c|c|c|c|c|c|}
\hline \multirow[b]{2}{*}{ Treatment } & \multicolumn{6}{|c|}{ Storage in week } \\
\hline & 1 & 2 & 3 & 4 & 5 & Mean \\
\hline \multicolumn{7}{|c|}{ Water loss rate ( $\mathrm{g} \mathrm{H}_{2} \mathrm{O} / \mathrm{kg}$ onion per day) } \\
\hline Cut & $2.92 \mathrm{a}^{\mathrm{z}}$ & $2.50 \mathrm{a}$ & $1.79 \mathrm{a}$ & $2.13 \mathrm{a}$ & $1.97 \mathrm{a}$ & $2.26 \mathrm{a}$ \\
\hline Cut + drop & $3.04 \mathrm{a}$ & $2.37 \mathrm{a}$ & $1.71 \mathrm{a}$ & $2.03 \mathrm{a}$ & $1.77 \mathrm{a}$ & $2.18 \mathrm{a}$ \\
\hline Drop & $0.91 \mathrm{~b}$ & $0.62 \mathrm{~b}$ & $0.79 \mathrm{~b}$ & $1.37 \mathrm{~b}$ & $1.10 \mathrm{~b}$ & $0.96 \mathrm{~b}$ \\
\hline Control & $0.79 \mathrm{~b}$ & $0.55 \mathrm{~b}$ & $0.76 \mathrm{~b}$ & $1.26 \mathrm{~b}$ & $0.95 \mathrm{a}$ & $0.86 \mathrm{~b}$ \\
\hline \multicolumn{7}{|c|}{ Total weight loss $(\%)^{y}$} \\
\hline Cut & $2.4 \mathrm{a}^{\mathrm{z}}$ & $4.0 \mathrm{a}$ & $5.3 \mathrm{a}$ & $7.5 \mathrm{a}$ & $9.3 \mathrm{a}$ & \\
\hline Cut + drop & $2.5 \mathrm{a}$ & $4.0 \mathrm{a}$ & $5.2 \mathrm{a}$ & $8.3 \mathrm{a}$ & $10.5 \mathrm{a}$ & \\
\hline Drop & $0.8 \mathrm{~b}$ & $1.8 \mathrm{~b}$ & $2.6 \mathrm{~b}$ & $5.6 \mathrm{~b}$ & $8.4 \mathrm{a}$ & \\
\hline Control & $0.7 \mathrm{~b}$ & $1.3 \mathrm{~b}$ & $2.4 \mathrm{~b}$ & $3.3 \mathrm{~b}$ & $4.0 \mathrm{~b}$ & \\
\hline
\end{tabular}

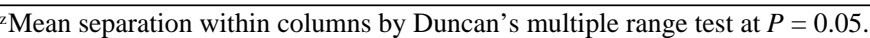

yTotal weight loss was cumulative and included water loss (drying) and weight loss due to discarded bulbs 